Launch Conference Announcement and Call for Papers "Regulating Moral Hazard"

Inaugural Conference of the Journal of Financial Regulation Paris, France | 11-12 July 2014

The threat of moral hazard has played an influential role in shaping post-crisis policy debates about the optimal role and limits of financial regulation as a means of constraining socially excessive risk-taking. Simultaneously, however, our understanding of moral hazard - its potential sources, its impact on financial markets and institutions, and the most appropriate regulatory responses - is far

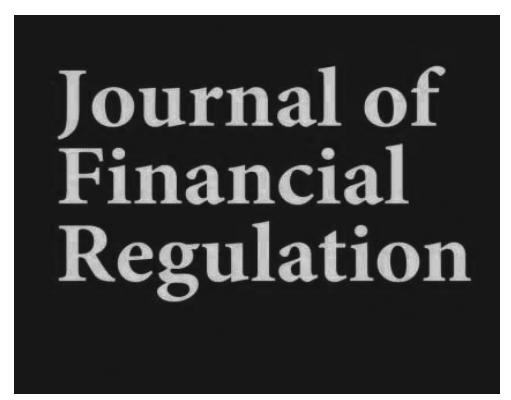
from complete. Where does moral hazard reside within the financial system? How does it influence the decisions of market participants, financial regulators, and elected policymakers? How can we identify and measure its impact? What role does financial regulation play in generating it? And, most importantly, what role can regulation play in preventing - or at the very least minimizing - its pernicious effects?

"Regulating Moral Hazard" will seek to enhance our understanding of these and other important questions. More specifically, the conference will seek to explore topics including, but not limited to:

- The sources of moral hazard within the financial system. The 'sources' of moral hazard in this context can be understood as referring to both the location of socially excessive risk-taking (e.g. systemically important financial institutions, the shadow banking system, etc.) as well as its underlying causes (e.g. implicit and explicit state guarantees, the provision of liquidity by central banks, the interdependent relationship between sovereigns and domestic financial services sectors, etc.);

- The relationship between the increasingly integrated structure of the global financial system, the largely fragmented regulatory system which governs it, and the ability of both public and private sector actors to externalize their socially excessive risk-taking;

- Regulatory responses on a global or regional level to constrain the moral hazard of sovereigns - including, for example, the evolving role of the European Central Bank and new Single Supervisory Mechanism/Resolution Mechanisms and their impact on moral hazard in the Eurozone;

- The emerging role of the U.S. Federal Reserve as de facto global lender of last resort and its impact on moral hazard at the global level;

- The role and limits of both conventional regulatory tools (e.g. risk-based supervision and capital requirements) and recent regulatory reforms (e.g. liquidity requirements, bail-in and structural regulation) in constraining moral hazard within financial institutions; and

- The role of constitutional and administrative law, as well as other forms of public sector governance, in generating or constraining moral hazard.

The conference organizers invite papers from scholars, policymakers and practitioners on each of these topics. The organizers encourage the submission of papers which examine these topics from an interdisciplinary, international and/or comparative perspective.

\title{
Submission Process
}

All papers should be submitted via email to Geneviève Helleringer at genevieve.helleringer@law.ox.ac.uk. The subject line of the email should state "JFR Inaugural Conference Submission". Authors who wish to have their conference submission considered for the inaugural issue of the JFR should also submit their paper via the ScholarOne link available on the journal's website: jfr.oxfordjournals.org.

The deadline for submission of papers for the conference is February 1st, 2014. Authors will be notified regarding whether their paper has been accepted for presentation at the conference by April 1st, 2014.

\section{About the Journal of Financial Regulation}

The Journal of Financial Regulation is a peer-reviewed journal dedicated to examining theoretical, policy and practicerelated issues in the area of financial regulation. The journal seeks to publish world-class scholarship which examines these issues from an interdisciplinary, international, and comparative perspective. The journal is published by Oxford University Press. Further information about the journal - including its aims and objectives, submission process, and subscription details - is available on the journal's website: jfr.oxfordjournals.org.

The JFR is edited by Dan Awrey (Oxford), Thierry Bonneau (Paris), Chris Brummer (Georgetown), Georg Ringe (Copenhagen and Oxford), Geneviève Helleringer (Essec Business School and University of Oxford), and Marco Ventoruzzo (Bocconi and Penn State). 


\section{(9) FLEMING}

\section{NAVIGATE YOUR \\ PHARMACOVIGILANCE BOAT TOWARDS SAFETY}

而

-

$4^{\text {th }}$ Annual

PHARMACOVIGILANCE \& RISK MANAGEMENT STRATEGIES

23 - 24 January 2014, Amsterdam

www.flemingeurope.com | andrea.weber@flemingeurope.com|T: + 421257272160 


\section{Conferences, Seminars \& Trainings}

\author{
EU Food Law \\ EFFL Spring College focused on Health \& Nutrition \\ Claims and Food Information, \\ 27-28 March 2014, Brussels \\ EFFL Seminar, \\ May 2014, Brussels \\ $\square 8^{\text {th }}$ International EFFL Conference \\ 16-17 October 2014, Vienna
}

\section{State Aid Law: Trainings}

$\square$ State Aid Evaluation, 27-28 January 2014, Brussels

$\square$ Essentials of State Aid Law and Procurement, 24-25 February 2014, Brussels

$\square$ State Aid for the Agricultural Sector, 7-8 April, Brussels

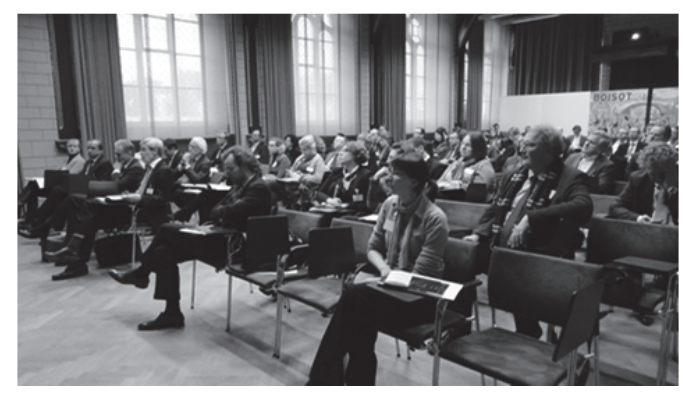

\section{European State Aid Law Institute}

EStALI Seminar: The new General Block Exemption Regulation (GBER), 24-26 April 2014, Feldafing, Lake Starnberg (near Munich)

\section{Public Procurement \& PPPs}

Training: Remedies in Public Procurement, 3-4 February 2014, Brussels

EPPPL Conference: New EU Concessions Directive,

25 March 2014, Brussels

More information? Return via Fax: +49(0)30-8145 0622 or e-mail: info@lexxion.de

Please send more information about the chosen event/s to me.

Lexxion Verlagsgesellschaft $\mathrm{mbH}$

Güntzelstraße 63 | D- 10717 Berlin

Tel: +49(0)30-8145060

Fax: +49(0)30-81450622

e-mail: info@lexxion.de

www.lexxion.eu/conferences www.lexxion.eu/training

\section{Name}

Institution

Address

Postal Code / Country

E-Mail

Date/Signature 


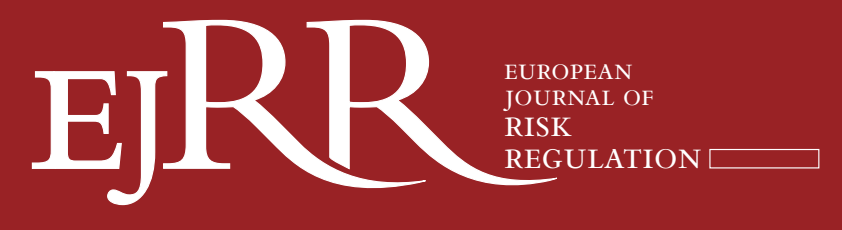

\section{A JOURNAL AT THE INTERSECTION OF LAW, SCIENCE AND POLICY}

Today the most important and widespread form of EU regulation in the internal market is concerned with the government of risk to individuals' health and safety. The European Journal of Risk Regulation (EJRR) provides an innovative forum for informed discussion on how these risks are regulated across policy domains in Europe and beyond. The central focus of the journal is the European Law and Policy regulating inter alia product (chemicals, food, pharma), financial, insurance and lifestyle risks (nutrition, alcohol, tobacco) as well as risks emerging from technology and third-party threats such as terrorism. The journal adopts a wide definition of regulation, including also innovative forms such as self-, co-regulation and nudges. Its methods extend to disciplines such as law, sociology, political science, risk analysis, economics as well as psychology and cognitive studies.

EJRR strikes a balance between the interests of the practitioners, notably those increasingly engaged in regulatory drafting and advice to the industry, and a more theoretical focus, combining normative articles with timely contributions on legislative and judicial developments, new literature and relevant events. 